\title{
CORRELATION BETWEEN SUNSHINE HOURS AND CLIMATIC PARAMETERS AT FOUR LOCATIONS IN UGANDA
}

\author{
K Karume $^{1}$, EJKB Banda ${ }^{1}$, J Mubiru ${ }^{1}$ and M Majaliwa ${ }^{2}$ \\ 1. Department of Physics, Makerere University, P.O.Box 7062, Kampala, Uganda \\ 2. Department of Soil Science, Makerere University, P.O.Box 7062, Kampala Uganda
}

\begin{abstract}
One of the most important factors in solar energy production is related to the predictability of sunshine hours. The objective of this study is to assess the correlation between sunshine hours and relative humidity, cloud cover, maximum and minimum temperature, for the purpose of identifying the most appropriate parameter(s) for the prediction of sunshine hours in Uganda. Climatic data for the meteorological stations of Entebbe, Mbarara, Tororo and Makerere, extending over a period of 15 years (1990-2005) was collected from the Department of Meteorology, Kampala. The data set included maximum temperature, minimum temperature, relative humidity at 6 am and at 12 noon, Cloud cover at 6 am and at 12 noon and Sunshine hours. A multiple regression technique was used to assess the correlation between sunshine hours and maximum and minimum temperatures, cloud cover at 6 am and at 12 noon and relative humidity at 6 am and at 12 noon. Results have shown that the availability of sunshine hours can be predicted by the use of maximum and minimum temperatures, relative humidity at 6 am and 12 noon and cloud cover at 6 am and at 12 noon in Uganda, but, principal components and factoraAnalysis have indicated that two parameters, especially relative humidity at noon or 6 am and Maximum temperature are enough to capture the variability of sunshine hours in Uganda.
\end{abstract}

\section{BACKGROUND}

Solar energy is one of the friendliest sources of energy as it does not produce any kind of pollutant. Owing to rapid technological development, megawatt-size solar plants are available. They are easy to operate and because of the lower maintenance costs, long project life and competitive cost of energy production, solar projects are being developed throughout the world (Hanne and Niels 1991, Karume et al. 2005, Otiti 1994, Karekezi 1995).

Naturally solar insolation increases with sunshine hours. Therefore, sunshine data can be used as input to predict the performance of concentrating solar energy systems (John and Tony 2000). However, it is not often possible to have solar radiation data at any location, owing to, among other things, insufficient solar radiation measuring equipment. Thus, it becomes necessary to estimate or model solar radiation for such locations. If the simulated data is to be reliable, it has to be accurately predicted. The accuracy with which one can predict solar radiation depends on the model and the climatic parameter used.

Recently there has been a growing trend towards the utilization of solar energy. New problems in the field of energy management and operation have emerged on the energy market. One of the most important factors in solar energy production is related to the predictability of sunshine hours (Firoz and Intikhab 2004, John and Tony 2000). This has resulted in non-optimal use of solar radiation. Therefore, the use of statistical methods for reliable predictions becomes inevitable (Ozerdem and Turkeli 2004, Naif 2004, Vogiatzis et al. 2003, Nfaoui et al. 2003, Jaramillo and Borja 2004, Flores et al. 2004, Firoz and Intikhab 2004). This will lead to more accurate prediction and to improvement in the efficiency of the solar installations. 
Statistical methods include factor analytic techniques such as principal components analysis (PCA) and principal factor analysis (PFA). The main applications of factor analytic techniques are: (1) to reduce the number of variables and (2) to detect structure in the relationships between variables, that is to classify variables (Kim and Mueller 1978, Hotelling 1933).

Principal components analysis seeks a linear combination of variables such that the maximum variance is extracted from the variables. It then removes this variance and looks for a second linear combination which explains the maximum proportion of the remaining variance, and so on.

Principal factor analysis: Also called principal axis factoring, PAF, and common factor analysis, is a form of factor analysis which looks for the least number of factors which can account for the common variance (correlation) of a set of variables, whereas the more common principal components analysis (PCA) in its full form seeks the set of factors which can account for all the common and unique variance in a set of variables. PFA uses a PCA strategy but applies it to a correlation matrix in which the diagonal elements are not 1 's, as in PCA, but iteratively-derived estimates of the communalities $\left(\mathrm{R}^{2}\right.$ of a variable using all factors as predictors).

The question is how many factors do we want to extract? It has to be noted that as we extract consecutive factors, they account for less and less variability. The decision of when to stop extracting factors basically depends on when there is only very little "random" variability left. The nature of this decision is arbitrary; however, various guidelines have been developed, and they are reviewed in the literature (Thurstone 1947, Velicer 1976, Lawley 1940, Jöreskog and Sörbom 1979).

The objective of this study is to assess the correlation between sunshine hours and relative humidity, cloud cover, maximum and minimum temperature, for the purpose of identifying the most appropriate parameter(s) for the prediction of sunshine hours in Uganda. This paper reports on the analysis of recently collected climatic data at four locations in Uganda (Fig. 1). The locations are Tororo, Mbarara, Entebbe and Makerere. The correlation between sunshine hours and temperatures, relative humidity and cloud cover at the four sites, are presented.

This is needed because generation of electric energy using photovoltaic panels is increasingly becoming significant and has to compete with other energy sources that are not so variable in terms of generated active power. It is important to consider that active power demand can vary quite fast and different sources of electricity generation must be available. In the case of solar energy, sunshine hours and solar radiation predictions are important parameters which will help policy makers make the best decisions on potential contribution of solar energy in the national energy balance. 


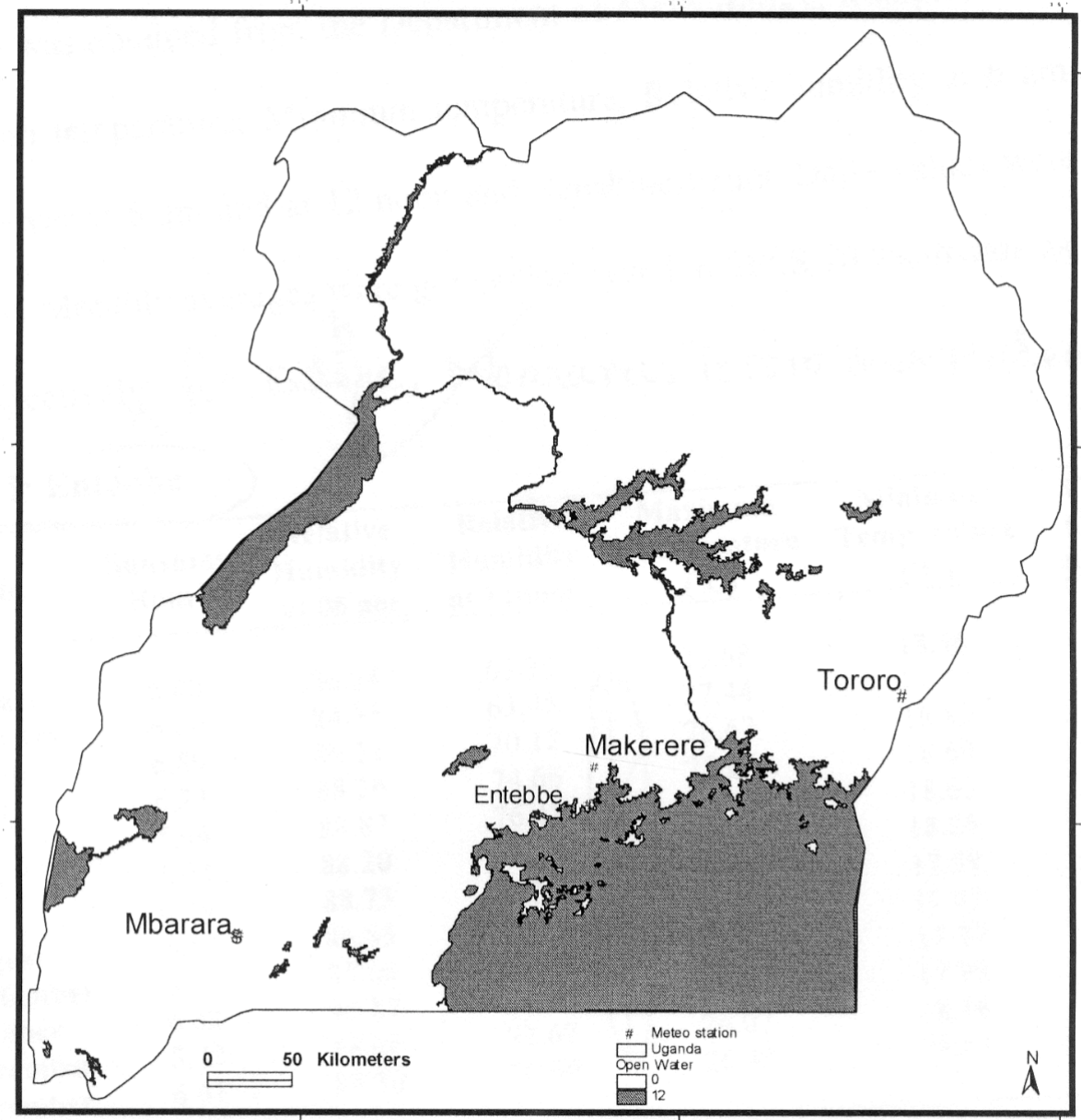

Figure 1: Locations of meteorological stations

\section{METHOD}

Climatic data for Entebbe, Mbarara, Tororo and Makerere stations covering a period of about 15 years was obtained from the Department of Meteorology, Kampala. The data set included maximum temperature, minimum temperature, relative humidity at
6 am and at 12 noon, cloud cover at 6 am and at 12 noon and sunshine hours. Daily values were entered in Excel software. Monthly averages were got and analyzed in SPSS 10.0 software as shown in Tables $1-$ 4, respectively for Entebbe, Mbarara, Tororo and Makerere. 
Karume et al. - Correlation between sunshine hours and climatic parameters ...

Table 1: Climatic data for Entebbe covering a period of 15 years

\begin{tabular}{lccccccc}
\hline Month & $\begin{array}{c}\text { Sunshine } \\
\text { Hours }\end{array}$ & $\begin{array}{c}\text { Relative } \\
\text { Humidity } \\
\text { at 06 am }\end{array}$ & $\begin{array}{c}\text { Relative } \\
\text { Humidity } \\
\text { at 12noon }\end{array}$ & $\begin{array}{c}\text { Maximum } \\
\text { Temperature } \\
\left.\mathbf{(}^{\mathbf{0}} \mathbf{C}\right)\end{array}$ & $\begin{array}{c}\text { Minimum } \\
\text { Temperature } \\
\left.\mathbf{(}^{\mathbf{0}} \mathbf{C}\right)\end{array}$ & $\begin{array}{c}\text { Cloud } \\
\text { Cover at } \\
\mathbf{6} \text { am }\end{array}$ & $\begin{array}{c}\text { Cloud } \\
\text { Cover } \\
\text { at 12noon }\end{array}$ \\
January & 6.40 & 86.54 & 65.35 & 26.78 & 18.46 & 6.20 & 5.70 \\
February & 6.84 & 84.35 & 63.45 & 27.56 & 18.80 & 6.10 & 5.70 \\
March & 6.89 & 86.32 & 70.12 & 27.13 & 18.80 & 6.60 & 6.10 \\
April & 6.23 & 88.26 & 74.66 & 26.20 & 18.69 & 6.80 & 6.20 \\
May & 5.94 & 88.87 & 76.48 & 25.95 & 18.65 & 6.70 & 5.90 \\
June & 6.03 & 88.20 & 73.14 & 26.43 & 18.25 & 6.40 & 6.10 \\
July & 6.39 & 88.73 & 71.97 & 26.95 & 17.59 & 6.10 & 5.80 \\
August & 6.51 & 86.85 & 70.94 & 27.36 & 17.47 & 6.20 & 5.90 \\
September & 6.65 & 85.06 & 69.02 & 27.24 & 17.77 & 6.10 & 5.90 \\
October & 6.32 & 85.57 & 71.25 & 26.27 & 17.93 & 6.60 & 6.20 \\
November & 5.72 & 88.06 & 72.67 & 25.52 & 18.18 & 6.70 & 6.30 \\
December & 6.61 & 88.30 & 70.99 & 25.87 & 18.53 & 6.40 & 5.80 \\
\hline
\end{tabular}

Table 2: $\quad$ Climatic data for Mbarara covering a period of 15 years

\begin{tabular}{lccccccc}
\hline Month & $\begin{array}{c}\text { Sunshine } \\
\text { Hours }\end{array}$ & $\begin{array}{c}\text { Relative } \\
\text { Humidity } \\
\text { at 06 am }\end{array}$ & $\begin{array}{c}\text { Relative } \\
\text { Humidity } \\
\text { at 12noon }\end{array}$ & $\begin{array}{c}\text { Maximum } \\
\text { Temperature } \\
\left.\mathbf{(}^{\mathbf{0}} \mathbf{C}\right)\end{array}$ & $\begin{array}{c}\text { Minimum } \\
\text { Temperature } \\
\left.\mathbf{(}^{\mathbf{0}} \mathbf{C}\right)\end{array}$ & $\begin{array}{c}\text { Cloud } \\
\text { Cover } \\
\text { at 6 am }\end{array}$ & $\begin{array}{c}\text { Cloud } \\
\text { Cover } \\
\text { at 12noon }\end{array}$ \\
\hline January & 5.42 & 88.75 & 53.98 & 26.78 & 18.46 & 6.60 & 6.80 \\
February & 5.13 & 87.24 & 51.38 & 27.56 & 18.80 & 6.80 & 6.90 \\
March & 4.78 & 87.22 & 56.12 & 27.13 & 18.80 & 6.90 & 6.70 \\
April & 5.36 & 89.73 & 63.90 & 26.20 & 18.69 & 6.80 & 6.70 \\
May & 6.11 & 87.62 & 62.51 & 25.95 & 18.65 & 6.60 & 6.70 \\
June & 5.92 & 80.58 & 51.70 & 26.43 & 18.25 & 6.50 & 6.80 \\
July & 5.91 & 82.20 & 45.16 & 26.95 & 17.59 & 0.50 & 6.80 \\
August & 5.75 & 81.69 & 47.53 & 27.36 & 17.47 & 6.60 & 6.80 \\
September & 5.93 & 82.68 & 52.33 & 27.24 & 17.77 & 6.40 & 6.90 \\
October & 5.18 & 85.76 & 63.72 & 26.27 & 17.93 & 6.70 & 6.90 \\
November & 4.79 & 88.13 & 65.22 & 25.52 & 18.18 & 6.60 & 6.80 \\
December & 5.28 & 89.82 & 62.81 & 25.87 & 18.53 & 6.70 & 6.80 \\
\hline
\end{tabular}

Table 3: $\quad$ Climatic data for Tororo covering a period of 15 years

\begin{tabular}{|c|c|c|c|c|c|c|c|}
\hline Month & $\begin{array}{l}\text { Sunshine } \\
\text { Hours }\end{array}$ & $\begin{array}{l}\text { Relative } \\
\text { Humidity } \\
\text { at } 06 \text { am }\end{array}$ & $\begin{array}{l}\text { Relative } \\
\text { Humidity } \\
\text { at 12noon }\end{array}$ & $\begin{array}{c}\text { Maximum } \\
\text { Temperature } \\
\left({ }^{\circ} \mathrm{C}\right) \\
\end{array}$ & $\begin{array}{c}\text { Minimum } \\
\text { Temperature } \\
\left({ }^{\circ} \mathrm{C}\right) \\
\end{array}$ & $\begin{array}{c}\text { Cloud } \\
\text { Cover at } \\
6 \mathrm{am} \\
\end{array}$ & $\begin{array}{c}\text { Cloud } \\
\text { Cover } \\
\text { at 12noon } \\
\end{array}$ \\
\hline January & 7.84 & 66.78 & 40.15 & 30.75 & 16.41 & 4.92 & 5.60 \\
\hline February & 7.83 & 67.73 & 42.88 & 31.53 & 16.77 & 4.87 & 5.70 \\
\hline March & 7.74 & 68.95 & 43.78 & 31.25 & 17.61 & 5.51 & 6.10 \\
\hline April & 6.93 & 77.31 & 55.06 & 29.61 & 17.72 & 6.14 & 6.40 \\
\hline May & 7.38 & 80.37 & 58.46 & 28.58 & 17.36 & 5.50 & 6.20 \\
\hline June & 6.51 & 81.66 & 58.44 & 28.15 & 16.65 & 5.50 & 6.30 \\
\hline July & 6.44 & 83.84 & 57.23 & 27.84 & 16.33 & 5.80 & 6.20 \\
\hline August & 6.71 & 81.27 & 54.58 & 28.43 & 16.10 & 5.50 & 6.40 \\
\hline September & 7.74 & 78.72 & 53.83 & 29.53 & 16.11 & 5.30 & 6.10 \\
\hline October & 7.54 & 75.90 & 55.48 & 29.58 & 16.59 & 5.80 & 6.40 \\
\hline November & 7.59 & 73.51 & 54.26 & 29.23 & 16.53 & 5.76 & 6.40 \\
\hline December & 8.37 & 65.53 & 43.99 & 30.13 & 16.21 & 5.00 & 5.80 \\
\hline
\end{tabular}


Table 4: Climatic data for Makerere covering a period of 15 years

\begin{tabular}{|c|c|c|c|c|c|c|c|}
\hline Month & $\begin{array}{c}\text { Sunshine } \\
\text { Hours }\end{array}$ & $\begin{array}{l}\text { Relative } \\
\text { Humidity } \\
\text { at } 06 \text { am } \\
\end{array}$ & $\begin{array}{l}\text { Relative } \\
\text { Humidity } \\
\text { at 12noon } \\
\end{array}$ & $\begin{array}{c}\text { Maximum } \\
\text { Temperature } \\
\left({ }^{\circ} \mathrm{C}\right) \\
\end{array}$ & $\begin{array}{c}\text { Minimum } \\
\text { Temperature } \\
\left({ }^{\circ} \mathrm{C}\right) \\
\end{array}$ & $\begin{array}{c}\text { Cloud } \\
\text { Cover at } \\
6 \text { am } \\
\end{array}$ & $\begin{array}{c}\text { Cloud } \\
\text { Cover } \\
\text { at } 12 \text { noon } \\
\end{array}$ \\
\hline January & 5.88 & 78.27 & 54.26 & 28.36 & 17.45 & \multirow{12}{*}{ NA } & \multirow{12}{*}{ NA } \\
\hline February & 7.00 & 75.69 & 49.92 & 29.51 & 17.97 & & \\
\hline March & 6.21 & 79.96 & 56.23 & 28.51 & 17.94 & & \\
\hline April & 6.00 & 80.63 & 61.41 & 27.61 & 17.88 & & \\
\hline May & 5.87 & 81.54 & 64.05 & 27.20 & 17.83 & & \\
\hline June & 5.90 & 80.45 & 61.60 & 26.94 & 17.27 & & \\
\hline July & 5.43 & 81.80 & 61.41 & 26.63 & 16.76 & & \\
\hline August & 5.88 & 81.19 & 59.71 & 27.22 & 16.64 & & \\
\hline September & 6.01 & 79.76 & 57.69 & 55.81 & 16.85 & & \\
\hline October & 5.58 & 80.56 & 63.95 & 27.47 & 17.07 & & \\
\hline November & 4.91 & 80.78 & 63.31 & 27.27 & 17.05 & & \\
\hline December & 5.64 & 79.06 & 58.02 & 27.85 & 17.32 & & \\
\hline
\end{tabular}

NA: Not Available

Simple patterns in the relationships among the variables (Kim and Mueller 1978, Horn 1965) were assessed using Factor Analysis (Hotelling 1933). The method chosen will matter more to the extent that the sample is small, the variables are few, and/or the communality estimates of the variables differ.
Eigenvalues and the Number-of-Factors were computed in SPSS Software. In this study the Kaiser criterion (Kaiser, 1960) was used: First, were retained only factors with eigenvalues greater than 1 . Secondly, the scree test was applied by plotting eigenvalues as proposed by Cattell (1966). Simple line eigenvalues were plotted as shown below.

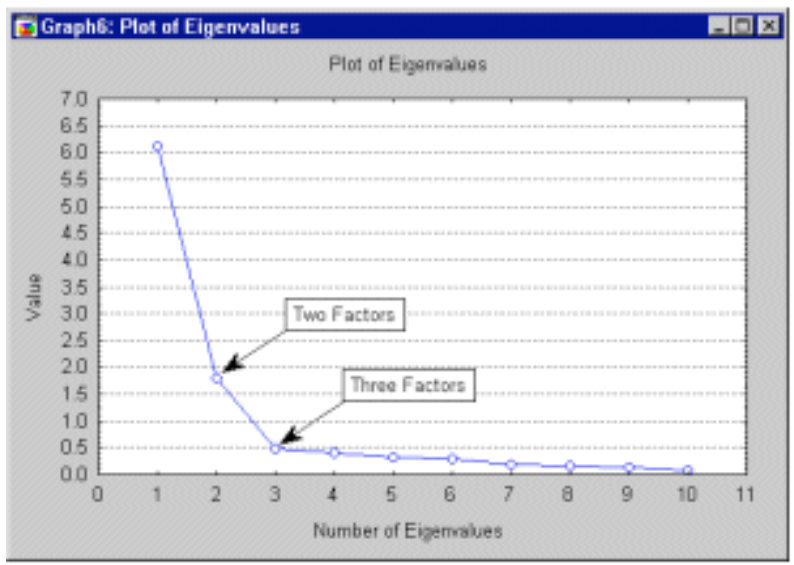

Figure 2: $\quad$ Simple line eigenvalues

Place where the smooth decrease of eigenvalues appears to level off to the right of the plot was determined. To the right of this point, presumably, one finds only "factorial scree". This criterion, allows probably the retention of 2 or 3 factors in the above example (Cattell 1966).

The correlation between sunshine hours and maximum and minimum temperatures, cloud cover at 6 am and at 12 noon and 
relative humidity at 6 am and 12 noon was assessed by multiple regression technique. Stepwise approach was used in the analysis. Multivariate methods for data including principal components analysis, scree plot, component plot in rotated space and factor analysis were also performed.

\section{RESULTS AND DISCUSSION}

Table 5 shows the strength of the correlation between sunshine hours ( $\mathrm{SH}$ ) and maximum and minimum temperatures $\left(\mathrm{T}_{\max }\right.$ and $\left.\mathrm{T}_{\min }\right)$, Relative Humidity and Cloud Cover at 6 am and 12 noon (RH and $\mathrm{CC})$.

Table 5: Correlation between sunshine hours and the selected climatic parameters

\begin{tabular}{|c|c|c|c|c|c|c|c|c|c|c|}
\hline $\begin{array}{l}\text { Station } \\
\text { Name }\end{array}$ & & $\begin{array}{l}\text { SH\& } \\
\mathbf{R H}_{06}, \\
\mathbf{R H}_{12}\end{array}$ & $\begin{array}{l}\text { SH\& } \\
\mathbf{R H}_{12}, \\
\mathbf{T}_{\max }\end{array}$ & $\begin{array}{l}\text { SH\& } \\
\text { RH }_{06}, \\
T_{\max }\end{array}$ & $\begin{array}{l}\text { SH\& } \\
\mathbf{R H}_{06}, \\
\mathbf{R H}_{12}, \\
\mathbf{T}_{\max }\end{array}$ & $\begin{array}{l}\mathrm{SH} \& \\
\mathrm{RH}_{06} \mathrm{RH}_{1} \\
{ }_{2}, \mathrm{~T}_{\text {min }}\end{array}$ & $\begin{array}{l}\mathrm{SH} \& \\
\mathrm{RH}_{12} \\
\mathrm{~T}_{\max }, \\
\mathrm{T}_{\min }\end{array}$ & $\begin{array}{l}\text { SH\& } \\
\text { RH }_{06} \\
\mathbf{T}_{\max }, \\
\mathbf{T}_{\min }\end{array}$ & $\begin{array}{l}\mathrm{SH} \& \\
\mathrm{RH}_{06} \\
\mathrm{RH}_{12}, \\
\mathbf{T}_{\max }, \\
\mathbf{T}_{\min }\end{array}$ & $\begin{array}{l}\text { SH \& } \\
\text { RH }_{06} \\
\mathbf{R H}_{12}, \\
\mathbf{T}_{\text {max }}, \\
\mathbf{T}_{\text {min, }} \\
\text { CC06, } \\
\text { CC12 }\end{array}$ \\
\hline Makerere & $\mathrm{R}$ & 0.75 & 0.74 & 0.69 & 0.75 & 0.82 & 0.84 & 0.78 & 0.84 & \\
\hline Mbarara & $\mathrm{R}$ & 0.59 & 0.58 & 0.60 & 0.64 & 0.59 & 0.60 & 0.61 & 0.65 & 0.66 \\
\hline Tororo & $\mathrm{R}$ & 0.88 & 0.77 & 0.85 & 0.88 & 0.89 & 0.81 & 0.86 & 0.91 & 0.93 \\
\hline Entebbe & $\mathrm{R}$ & 0.69 & 0.69 & 0.68 & 0.70 & 0.70 & 0.70 & 0.69 & 0.70 & 0.79 \\
\hline
\end{tabular}

The strongest linear correlation was observed when all parameters were considered $(\mathrm{R}=0.66$ to 0.93 ), followed by the case where sunshine hours was correlated with $\mathrm{RH}_{12}, \mathrm{~T}_{\max }$, and $\mathrm{T}_{\min }(\mathrm{R}=0.60$ to 0.84$)$. This is confirmed by principal components analysis and factor analysis performed in SPSS 10.0 software.

\section{Makerere}

Total variance table and scree plot showed that two factors can explain $83 \%$ of sunshine hour's variability. The two factors were $T_{\max }$ and $\mathrm{RH}_{06}$ or $\mathrm{RH}_{12}$.

The correlation matrix table showed that there was a correlation between sunshine hours and $\mathrm{T}_{\max }$ and a strong relation between $\mathrm{RH}_{06}$ and $\mathrm{RH}_{12}(\mathrm{R}=0.89)$.

Finally the component plot in rotated space showed that sunshine hours can best be expressed in terms only of $\mathrm{T}_{\max }$ with $\mathrm{RH}_{12}$ or $\mathrm{T}_{\max }$ with $\mathrm{RH}_{06}$.

\section{Mbarara}

Total variance table and scree plot showed that two factors can capture $83 \%$ of sunshine hour's variability. Strong correlations were observed between sunshine hours and $\mathrm{T}_{\max }$ ' and between $\mathrm{RH}_{06}$ and $\mathrm{RH}_{12}$ and $\mathrm{T}_{\min }$.
In rotated space, it appears that sunshine hours can be expressed in terms of $\mathrm{T}_{\max }$ with $\mathrm{RH}_{12}$ or $\mathrm{T}_{\max }$ with $\mathrm{RH}_{06}$ or $\mathrm{T}_{\max }$ with $\mathrm{T}_{\min }$.

\section{Tororo}

As for Mbarara and Makerere, total variance and scree plot demonstrated that two factors can explain $92 \%$ of sunshine hour's variability.

The correlation matrix table showed that there was a correlation between sunshine hours and $\mathrm{T}_{\max }$ and a strong relation between $\mathrm{RH}_{06}$ and $\mathrm{RH}_{12}(\mathrm{R}=0.93)$ and a good correlation between $T_{\max }$ and $T_{\min }$.

In addition, the component plot in rotated space showed that sunshine hours can be expressed in terms of $\mathrm{T}_{\max }$ with $\mathrm{RH}_{12}$ and/or $\mathrm{RH}_{06}$. The addition of cloud cover data improve the correlation coefficient and leads one to affirm that cloud cover is a useful parameter when it comes to predicting sunshine hours in Tororo. 


\section{Entebbe}

Total variance table and scree plot show that two factors can capture $86 \%$ of sunshine hour's variability.

The correlation matrix table showed that there was a correlation between sunshine hours and $\mathrm{T}_{\min }$ and a strong relation between $\mathrm{RH}_{06}$ and $\mathrm{RH}_{12}(\mathrm{R}=0.78)$.

The component plot in rotated space shows that sunshine hours can be expressed in terms of $\mathrm{T}_{\max }$ with $\mathrm{RH}_{12}$ or $\mathrm{RH}_{06}$.

The low correlation observed for Mbarara and Entebbe could be related to local climatic influence from the Lake Victoria for Entebbe and repetitive dry conditions in Mbarara. The repetitive dry conditions can be explained by the presence of the high mountains in the Rift valley; clouds are formed and as they move from Democratic Republic of Congo to Uganda, they loose the rain on the Rift Mountains. By the time they reach Mbarara they are dry. On the other hand, Entebbe is surrounded by Lake Victoria, hence clouds are humid due to evapotranspiration.

A similar situation has been observed in Norway by Løvseth (1983). The region Lesja, which is a high altitude mountain valley in upper Gudbrandsdal (central Norway), is the driest region in Norway, yet it receives moderate sunshine. The clouds are created and loose rain on the westerly hills. When the clouds reach Lesja they do not give rain - they are newly created but dry. Further East, the clouds loose height, evaporate and an increase of sunshine results. Thus it is typically on the plains behind the mountain shadow that an increase in sunshine will result.

\section{CONCLUSION}

Principal components analysis, scree plot, component plot in rotated space and factor analysis have demonstrated that two parameters are enough to capture the variability of sunshine hours in Uganda. Of the climatic parameters considered, RH6 and $\mathrm{T}_{\max }$ appear to give the best pair. Generally the more parameters one considers the better $\mathrm{R}^{2}$ is. Nevertheless, prediction of sunshine hours is site dependent as it was observed for Mbarara and Entebbe. However, there is need to perform calculation of mean bias error, root mean square error and others such as 't-test' in prediction of sunshine hours in order to come up with an acceptable model.

\section{ACKNOWLEDGMENTS}

The authors express their gratitude to Makerere University NUFU Basic Sciences Project 33/2002 for acquiring meteorological data used and for financial support.

\section{REFERENCES}

Ahmad F and Ulfat I, 2004 Empirical Models for the Correlation of Monthly Average Daily Global Solar Radiation with Hours of Sunshine on a Horizontal Surface at Karachi, Pakistan, TUBITAK, 28: 301 - 307.

Brevik I and Løvseth J Measurements and Modelling of Direct Solar Irradiance, Proceedings ISES, Solar World Congress, 1983.

Cattell RB 1966 The Scree test for the number of factors. Multivar. Behav. Res. 1, 245-276.

Flores P and Tapia G 2004 Application of a control algorithm for wind speed prediction and active power generation, Renew. Ener. 30: 523-536, Elsevier.

Graulund HB and Graulund NE 1991 Renewable energy for East Africa, The Danish Missionary Council Develonoonent Office, Copenhagen.

Horn JL 1965 A rationale and technique for estimating the number of factors in factor analysis. Psychometrika, 30: 179185.

Hotelling H 1933 Analysis of a complex of statistical variables into principal components. J. Educ. Psychol. 24: 417441 y 498-520.

Jaramillo OA and Borja MA 2004 Wind speed analysis in La Ventosa, Mexico: a 
bimodal probability distribution case, Renew. Ener. 29:1613-1630, Elsevier.

Jöreskog KG \& Sörbom D 1979 Advances in factor analysis and structural equation models. Cambridge, MA:

Kaiser HF 1960 The application of electronic computers to factor analysis. Educ. Psychol. Meas. 20: 141-151.

Karekezi S 1995 Renewable Energy Technologies as an option for a lowcarbon Energy Future for Developing Countries: Case Example from Eastern and Southern Africa, AFREPREN, Nairobi.

Karume K, Mubiru J, Kakeeto J and Majaliwa M 2005 Use of Solar Energy to Power Road Traffic Lights in Uganda, $2^{\text {nd }}$ Asian Renewable Energy Fair \& Conference (REAsia 2005), May 23-27, China International Exhibition Centre, Beijing.

Kim J, Mueller CW 1978 An introduction to factor analysis: What it is and how to do it. Beverly Hills, CA: Sage.

Lawley DM 1940 The estimation of factor loadings by the method of maximum likelihood. Proc. Roy. Soc. Edin. 60: 64-82.

Naif M and Al-Abbadi 2004. Wind energy resource assessment for five locations in
Saudi Arabia, Renew. Ener. 30: 1489-1499.

Nfaoui H, Essiarab H and Sayigh AA 2003. A stochastic Markov chain model for simulating wind speed time series at Tangiers, Morocco, Renew. Ener. 29: 1407-1418.

Otiti T 1994 Renewable Energy Technologies: The case of Uganda, African Regional Energy and Environment Policy Seminar, Nairobi, AFREPREN.

Ozerdem B and Turkeli HM 2004 Wind energy potential estimation and micrositting on Izmir Institute of Technology Campus, Turkey, Renew. Ener. 30: 1623-1633.

Thurstone LL 1947 Multiple Factor Analysis. Chicago: University of Chicago Press.

Twidell J and Weir T 2000 Renewable Energy Resources, Spon Press

Velicer WF 1976 Determining the number of components from the matrix of partial correlations. Psychometrika, 41: 321327.

Vogiatzis N, Kotti K, Spanomitsios S and Stoukides M 2003. Analysis of wind potential and characteristics in North Aegean, Greece, Renew. Ener. 29: 1193-1208. 